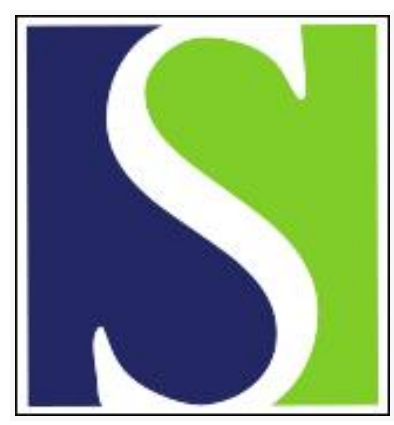

Scand J Work Environ Health 1992;18(3):178-185

https://doi.org/10.5271/sjweh.1590

Issue date: 01 Jun 1992

Differences in the incidence of myocardial infarction among occupational groups.

by Hammar N, Alfredsson L, Smedberg M, Ahlbom A

Affiliation: Department of Epidemiology, Karolinska Institute, Stockholm, Sweden.

The following articles refer to this text: SJWEH Supplements 2009;(7):24-29; 2013;39(2):204-211

This article in PubMed: www.ncbi.nlm.nih.gov/pubmed/1615292 


\title{
Differences in the incidence of myocardial infarction among occupational groups
}

\author{
by Niklas Hammar, BA, ${ }^{1}$ Lars Alfredsson, $\mathrm{PhD},{ }^{1,2}$ Martina Smedberg, BA, ${ }^{1}$ Anders Ahlbom, $\mathrm{PhD}^{1}$
}

\begin{abstract}
HAMMAR N, ALFREDSSON L, SMEDBERG M, AHLBOM A. Differences in the incidence of myocardial infarction among occupational groups. Scand J Work Environ Health 1992;18:178-85. An inverse relationship between social class and coronary heart disease has been observed in several countries, but few studies have investigated the incidence of this disease over different occupational groups. A case-referent study was carried out to estimate the relative risk of a first myocardial infarction in various occupational groups. Cases of myocardial infarction $(\mathrm{N}=36602)$ were identified from both hospital discharge and death records. Two referents for each case were randomly selected from the study base. Information about occupation was obtained from two consecutive censuses. An increased incidence, compared with that of others employed, was found for persons in some occupations in production work, transport work (men), and service work (women). Low relative risks were found mainly for persons in occupations demanding a high education. The relative risks ranged from 0.3 to 2.8 . Several factors, occupational as well as nonoccupational, may be of importance in explaining the findings.
\end{abstract}

Key terms: case-referent studies, epidemiology, registers.

A greater mortality from coronary heart disease has been reported for manual than for nonmanual occupations in several Western countries (1-4). In Great Britain, these differences were observed to have increased during the 1970s (5). Although the differences are caused to some extent by nonoccupational factors, it is likely that occupational factors are also involved. It has been suggested that psychosocial factors in the work environment, particularly a combination of high demands and poor control, may have contributed to the differences in coronary heart disease between socioeconomic groups (6). Several other factors in the work environment, including physical and chemical factors, may also have contributed (7).

Few studies have investigated coronary heart disease in different occupations. In a review (8), Kristensen \& Damsgaard pointed out that increased rates of cardiovascular disease have been suggested by European and North American studies among motor-vehicle drivers, fishermen, hotel and restaurant workers, ships' crews, and unskilled manual workers. Low rates have been indicated for persons in some occupations demanding a high education and for persons engaged in agricultural, horticultural, and forestry work. A comprehensive survey of coronary heart disease in different occupational groups, based on data for dis-

\footnotetext{
1 Department of Epidemiology, Institute of Environmental Medicine, Karolinska Institute, Stockholm, Sweden.

2 Department of Occupational Medicine, Karolinska Hospital, Stockholm, Sweden.
}

Reprint requests to: Mr N Hammar, Department of Epidemiology, Institute of Environmental Medicine, Karolinska Institutet, Box 60208, S-104 01 Stockholm, Sweden. ease incidence, has not, to our knowledge, previously been carried out.

The objective of the present study was to estimate the relative risk of a first myocardial infarction for subjects in different occupational groups. Furthermore, we wished to explore smoking habits among subjects in occupations associated with increased or decreased myocardial infarction incidence.

\section{Subjects and methods}

The study base consisted of the population $30-74$ years of age in four Swedish counties (Uppsala, Södermanland, Kopparberg, and Gävleborg) during 19761981 and in Stockholm County in 1976-1984. The relationship between occupation and myocardial infarction was studied by case-referent methods.

\section{Identification of cases}

From the national register on causes of death, all deaths with acute myocardial infarction as an underlying or contributory cause [International Classification of Diseases, 8th revision (ICD-8) code 410] were selected from the subjects of the study base. From a central register at the National Board of Health and Welfare and from a local register at the Stockholm County Council all the corresponding hospital discharges with acute myocardial infarction as the primary or secondary diagnosis (the Swedish version of the ICD-8 code 410.00 or 410.99 ) were obtained.

Cases of myocardial infarction were identified through the combined use of hospital-discharge and death records. These records can be linked with the 
use of Swedish personal identification numbers. The following main rules were applied to avoid double counting the same myocardial infarction episode: two discharges, or a discharge and death recorded for the same individual, were regarded as representing two myocardial infarction episodes if the time between hospital admissions, or between hospital admission and death, was more than $28 \mathrm{~d}$. Otherwise the two registrations were considered to reflect the same episode. This method has been developed and evaluated previously $(9,10)$.

In the present investigation, the goal was to study first myocardial infarctions. In order to classify infarctions with regard to first or recurrent events, information from the hospital-discharge registers about patients discharged with a diagnosis of acute myocardial infarction during the period $1972-1975$ was also utilized.

\section{Sample from the study base}

For each case, two individuals were selected from the study base (referents) through random sampling, stratified by gender, age (five year age groups), and year of hospital admission or death of the cases. For the selection of referents, registers of the total population of Sweden at the end of each year in 1976-1984 were used. After the selection of referents had been completed, it was discovered that 401 cases had been excluded from the case series. They were added to the study, and their referents were selected from the Swedish Twin Register (11) through stratified random sampling in the same fashion as the originally selected referents. The referents selected from the twin register were considered to reflect the distribution of occupations in the study base.

\section{Occupation, socioeconomic group and smoking}

Information about occupation was obtained from the 1970 and 1975 censuses by record linkage with the use of Swedish personal identification numbers. Almost all of the cases and referents (99\%) were identified in the censuses. A follow-up of nonmatches showed that they were predominantly persons who were not in the country at the time of the census. Occupation was coded in the censuses according to the Nordic modification of the three-digit International Standard Classification of Occupations. These codes covered basically the same occupational groups in the two censuses. However, for some occupations two or more codes had to be combined because of changes in the nomenclature.

Cases and referents were classified into the socioeconomic groups manual workers, nonmanual employees, and self-employed persons in accordance with principles used in the Swedish 1980 census (12). By using information about occupation and occupational status in the 1970 and 1975 censuses, we classified $97 \%$ of the cases and the referents for whom this information was available into these socioeconomic groups.

Information about smoking habits was extrapolated from the Swedish Twin Register (11). Data from this register regarding smoking has previously been found to be representative of the general population if differences in the age distribution are taken into account (13). We used data from a postal questionnaire sent to 21147 twin pairs in 1973 . The response rate was $83 \%$. The analyses were confined to subjects $30-$ 50 years of age in 1976 who belonged to the study base of the present study. Only one twin from each twin pair was used.

\section{Statistical methods}

The incidence density ratio (referred to as the relative risk) of a first myocardial infarction of subjects in a certain occupation, compared with other employment, was estimated by means of the following two comparisons: (i) persons who had been working in a certain occupation in both 1970 and 1975 were compared with others who had not changed occupation between 1970 and 1975 (occupationally stable) and (ii) persons who had been working in a certain occupation in 1970 or 1975 were compared with other persons employed in 1970 or 1975 .

Only occupations with at least 15 observed myocardial infarction cases were considered. In the tables, occupations with an increased incidence of myocardial infarction (defined as lower limit of the $95 \%$ confidence interval greater than or equal to 1.0 ) or a decreased incidence (defined as upper limit of the $95 \%$ confidence interval smaller than or equal to 1.0) are shown. If an occupation showed an increased or decreased incidence in both of the comparisons, only the results for the "occupationally stable" are presented.

Mantel-Haenszel estimates of relative risks (RR) (14), together with $95 \%$ confidence intervals (15), were computed from stratified analyses in which age (5-year age groups), county, calendar year, and socioeconomic group were taken into account. All of the analyses were carried out for the men and women separately. Regarding smoking, differences between proportions, together with $95 \%$ confidence intervals, were computed with the Depid computer program (16).

\section{Results}

\section{Myocardial infarction}

Altogether 36602 cases of first myocardial infarction were identified in the study base (26 847 men and 9755 women) (table 1). These cases constituted $77 \%$ of all of the myocardial infarction cases (first and recurrent infarctions).

Of the 173 occupations analyzed for the men, 27 showed an increased incidence of a first myocardial infarction (table 2). About half of these occupations 
Table 1. Total number of myocardial infarction (MI) cases and number of first $\mathrm{Ml}$ cases by gender and age.

\begin{tabular}{|c|c|c|c|c|c|c|}
\hline \multirow{3}{*}{ Age (years) } & \multicolumn{3}{|c|}{ Men } & \multicolumn{3}{|c|}{ Women } \\
\hline & \multirow{2}{*}{$\begin{array}{l}\text { All MI cases } \\
(\mathrm{N})\end{array}$} & \multicolumn{2}{|c|}{ First MI cases } & \multirow{2}{*}{$\begin{array}{l}\text { All MI cases } \\
(\mathrm{N})\end{array}$} & \multicolumn{2}{|c|}{ First $\mathrm{Ml}$ cases } \\
\hline & & $N$ & $\% a$ & & $\mathbf{N}$ & $\%$ \\
\hline $\begin{array}{l}30-39 \\
40-49 \\
50-59 \\
60-69 \\
70-74\end{array}$ & $\begin{array}{r}339 \\
2097 \\
7771 \\
15539 \\
9191\end{array}$ & $\begin{array}{r}299 \\
1711 \\
6108 \\
11760 \\
6969\end{array}$ & $\begin{array}{l}88 \\
82 \\
79 \\
76 \\
76\end{array}$ & $\begin{array}{r}91 \\
304 \\
1497 \\
5364 \\
5048\end{array}$ & $\begin{array}{r}85 \\
257 \\
1267 \\
4217 \\
3929\end{array}$ & $\begin{array}{l}93 \\
85 \\
85 \\
79 \\
78\end{array}$ \\
\hline Total & 34937 & 26847 & 77 & 12304 & 9755 & 79 \\
\hline
\end{tabular}

a Percentage of all MI cases.

Table 2. Occupations with an increased incidence of a first myocardial infarction among the men. $(95 \% \mathrm{Cl}=95 \%$ confidence interval)

\begin{tabular}{|c|c|c|c|c|}
\hline \multirow[t]{2}{*}{ Occupation ${ }^{a}$} & \multicolumn{2}{|c|}{$\begin{array}{l}\text { Relative risk (RR) adjusted } \\
\text { for age, county and } \\
\text { calendar year }\end{array}$} & \multicolumn{2}{|c|}{$\begin{array}{l}\text { Relative risk (RR) adjusted } \\
\text { for age, county and } \\
\text { socioeconomic group }\end{array}$} \\
\hline & RR & $95 \% \mathrm{Cl}$ & RR & $95 \% \mathrm{Cl}$ \\
\hline Certain metal processing workers ${ }^{b}$ & 2.8 & $1.4-5.8$ & 2.8 & $1.4-5.6$ \\
\hline Stonecutters and carvers ${ }^{c}$ & 2.0 & $1.2-3.6$ & 1.9 & $1.1-3.4$ \\
\hline Frame and circular sawyers and planers & 1.8 & $1.0-3.0$ & 1.7 & $1.0-3.0$ \\
\hline Paper and paperboard workers & 1.8 & $1.1-2.9$ & 1.6 & $1.0-2.7$ \\
\hline Ship's deck officers & 1.8 & $1.0-3.2$ & 1.9 & $1.0-3.4$ \\
\hline Road traffic supervisors & 1.7 & $1.1-2.6$ & 1.9 & $1.2-2.9$ \\
\hline Air traffic controllers, flight dispatchers ${ }^{c}$ & 1.7 & $1.0-2.9$ & 1.8 & $1.1-3.3$ \\
\hline Bus and tram conductors, traffic assistants ${ }^{c}$ & 1.6 & $1.0-2.5$ & 1.5 & $0.9-2.3$ \\
\hline Farm managers and supervisors $c$ & 1.5 & $1.0-2.5$ & 1.6 & $1.0-2.6$ \\
\hline Plastics product workers ${ }^{c}$ & 1.5 & $1.1-2.0$ & 1.4 & $1.0-1.9$ \\
\hline Railroad engineers and assistants & 1.4 & $1.1-1.8$ & 1.3 & $1.0-1.7$ \\
\hline Motor-vehicle drivers, tram drivers & 1.4 & $1.2-1.5$ & 1.3 & $1.1-1.4$ \\
\hline Construction machine operators & 1.4 & $1.0-1.9$ & 1.3 & $1.0-1.8$ \\
\hline Catering supervisors ${ }^{c}$ & 1.4 & $1.1-1.7$ & 1.5 & $1.1-1.9$ \\
\hline Building caretakers & 1.3 & $1.1-1.6$ & 1.3 & $1.0-1.5$ \\
\hline Working proprietors, retail trade & 1.3 & $1.0-1.6$ & 1.3 & $1.0-1.6$ \\
\hline Paper pulp workers ${ }^{c}$ & 1.3 & $1.0-1.7$ & 1.3 & $1.0-1.7$ \\
\hline Butchers and meat preparers ${ }^{c}$ & 1.3 & $1.0-1.6$ & 1.2 & $1.0-1.5$ \\
\hline Mechanical engineers and technicians & 1.2 & $1.0-1.3$ & 1.3 & $1.1-1.5$ \\
\hline Property managers, store managers & 1.2 & $1.0-1.5$ & 1.3 & $1.0-1.6$ \\
\hline Furnacemen ${ }^{c}$ & 1.2 & $1.0-1.5$ & 1.2 & $1.0-1.4$ \\
\hline $\begin{array}{l}\text { Toolmakers, machine-tool setters and operators, } \\
\text { machinery fitters and machine assemblers }\end{array}$ & 1.2 & $1.1-1.3$ & 1.1 & $1.0-1.2$ \\
\hline Certain civilian protective service workers ${ }^{c, d}$ & 1.2 & $1.0-1.5$ & 1.2 & $1.0-1.4$ \\
\hline Welders and flame cutters ${ }^{c}$ & 1.1 & $1.0-1.3$ & 1.0 & $0.9-1.2$ \\
\hline Secretaries, typists and related work ${ }^{\mathrm{c}}$ & 1.1 & $1.0-1.2$ & 1.2 & $1.1-1.3$ \\
\hline Truck and conveyor operators ${ }^{c}$ & 1.1 & $1.0-1.3$ & 1.1 & $0.9-1.2$ \\
\hline Store and warehouse workers & 1.1 & $1.0-1.3$ & 1.1 & $0.9-1.3$ \\
\hline
\end{tabular}

a Persons working in a certain occupation in both 1970 and 1975 unless marked with superscript C.

b Excludes furnacemen, metal annealers, temperers and case-hardeners, rolling-mill workers, smiths and forgers, metal casters and molders and wire and tube drawers.

c Individuals working in the occupation in 1970 or 1975, compared with others employed in 1970 or 1975.

d Excludes firefighters, policemen, customs surveiliance officials, and prison and reformatory officials.

(13 of 27) concerned production work, and the most elevated relative risks were observed for certain metal processing workers (RR 2.8), stone cutters and carvers (RR 2.0), frame and circular sawyers, and paper and paperboard workers (RR 1.8). Relative risks on the order of 1.4 to 1.8 were found for six occupations in the field of transport work, including motor-vehicle drivers (RR 1.4). 
A decreased incidence of myocardial infarction was observed for 28 occupations among the men (table 3). Of these 28 occupations, 20 concerned professional, technical, administrative, or managerial work, and a particularly low relative risk was observed for lawyers in courts of law (RR 0.3), corporation and organization lawyers (RR 0.5), chemists and physicists (RR 0.5), and physicians, dentists, designers and composers and musicians (RR 0.6). A decreased incidence was also observed for three occupations in agriculture and forestry work (RR 0.8 to 0.9 ) and for five other occupations (RR 0.7 to 0.9 ).

Of the 53 occupations analyzed for the women, 10 showed an elevated relative risk of a first myocardial infarction (table 4). The most increased incidence was found for four occupations in production work ( $R R$ 1.8 to 2.5 ) and for subjects in civilian protective service work (RR 2.0). Elevated relative risks were also observed for kitchen assistants and building caretakers (RR 1.5), practical nurses and hospital orderlies (RR 1.4), cleaners (RR 1.2), and shop assistants (RR 1.1).

Relative risks between 0.4 and 0.7 were found for female government administrators, teachers, registered nurses, and physiotherapists and occupational therapists (table 5). A decreased incidence was also observed for female secretaries and waitresses (RR 0.8 to 0.9 ).

In general, the observed relative risks changed only little when socioeconomic group was taken into account in the analyses (tables 2-5). However, the rela-

Table 3. Occupations with a decreased incidence of a first myocardial infarction among the men. $(95 \% \mathrm{Cl}=95 \% \mathrm{confidence}$ interval)

\begin{tabular}{|c|c|c|c|c|}
\hline \multirow[t]{2}{*}{ Occupation ${ }^{\mathbf{a}}$} & \multicolumn{2}{|c|}{$\begin{array}{l}\text { Relative risk (RR) adjusted } \\
\text { for age, county and } \\
\text { calendar year }\end{array}$} & \multicolumn{2}{|c|}{$\begin{array}{l}\text { Relative risk (RR) adjusted } \\
\text { for age, county and } \\
\text { socioeconomic group }\end{array}$} \\
\hline & RR & $95 \% \mathrm{Cl}$ & RR & $95 \% \mathrm{Cl}$ \\
\hline Judges and other lawyers in courts of lawb & 0.3 & $0.2-0.6$ & 0.4 & $0.2-0.6$ \\
\hline Corporation and organization lawyers ${ }^{b}$ & 0.5 & $0.3-0.8$ & 0.5 & $0.3-0.9$ \\
\hline Chemists, physicists & 0.5 & $0.3-0.8$ & 0.5 & $0.3-0.9$ \\
\hline Physicians and surgeons & 0.6 & $0.5-0.9$ & 0.7 & $0.5-0.9$ \\
\hline Dentists & 0.6 & $0.4-1.0$ & 0.6 & $0.4-1.0$ \\
\hline Designers $^{b}$ & 0.6 & $0.4-1.0$ & 0.6 & $0.4-1.0$ \\
\hline Composers and musicians ${ }^{b}$ & 0.6 & $0.4-0.9$ & 0.6 & $0.4-1.0$ \\
\hline University and higher education teachers & 0.7 & $0.4-1.0$ & 0.7 & $0.5-1.1$ \\
\hline $\begin{array}{l}\text { Other business managers including managers } \\
\text { of specific functions }{ }^{c}\end{array}$ & 0.7 & $0.5-0.9$ & 0.7 & $0.6-0.9$ \\
\hline Economists, statisticians ${ }^{b}$ & 0.7 & $0.5-1.0$ & 0.8 & $0.6-1.1$ \\
\hline Bank employees ${ }^{b}$ & 0.7 & $0.5-1.0$ & 0.8 & $0.6-1.1$ \\
\hline Forest workers and log drivers & 0.8 & $0.6-0.9$ & 0.7 & $0.6-0.9$ \\
\hline $\begin{array}{l}\text { Working proprietors, agricultural, horticultural } \\
\text { and forestry contractors }\end{array}$ & 0.8 & $0.7-0.9$ & 0.7 & $0.6-0.9$ \\
\hline Government legislative and administrative workers & 0.8 & $0.7-1.0$ & 0.9 & $0.8-1.1$ \\
\hline $\begin{array}{l}\text { Architects, building and construction engineers } \\
\text { and technicians }\end{array}$ & 0.8 & $0.7-1.0$ & 0.9 & $0.8-1.1$ \\
\hline Teachers in theoretical subjects & 0.8 & $0.6-1.0$ & 0.9 & $0.6-1.1$ \\
\hline $\begin{array}{l}\text { Sculptors, painters, photographers and } \\
\text { commercial artists }^{b}\end{array}$ & 0.8 & $0.6-1.0$ & 0.7 & $0.6-1.0$ \\
\hline Journalists, editors ${ }^{b}$ & 0.8 & $0.6-1.0$ & 0.8 & $0.7-1.0$ \\
\hline Accountants and auditors ${ }^{b}$ & 0.8 & $0.6-1.0$ & 0.8 & $0.6-1.1$ \\
\hline Librarians, archivists, and curators ${ }^{b}$ & 0.8 & $0.6-1.0$ & 0.8 & $0.6-1.1$ \\
\hline Advertising salesmen ${ }^{b}$ & 0.8 & $0.7-1.0$ & 0.9 & $0.7-1.1$ \\
\hline General managers & 0.8 & $0.7-1.0$ & 0.9 & $0.7-1.1$ \\
\hline $\begin{array}{l}\text { Bricklayers, concrete and construction workers, } \\
\text { drivers and pipelayers }\end{array}$ & 0.9 & $0.8-1.0$ & 0.8 & $0.7-1.0$ \\
\hline $\begin{array}{l}\text { Electrical, electronics and telecommunications } \\
\text { engineers and technicians }\end{array}$ & 0.9 & $0.7-1.0$ & 1.0 & $0.8-1.1$ \\
\hline Bookkeepers, office cashiers ${ }^{b}$ & 0.9 & $0.7-1.0$ & 0.9 & $0.8-1.1$ \\
\hline Agricultural/livestock workers ${ }^{b}$ & 0.9 & $0.7-1.0$ & 0.8 & $0.7-1.0$ \\
\hline Certain engineers and technicians $s^{b, d}$ & 0.9 & $0.8-1.0$ & 1.0 & $0.9-1.1$ \\
\hline Plumbers and pipe fitters ${ }^{b}$ & 0.9 & $0.8-1.0$ & 0.8 & $0.7-1.0$ \\
\hline
\end{tabular}

a Individuals working in a certain occupation in both 1970 and 1975 unless marked with superscript b.

b Individuals working in the occupation in 1970 or 1975, compared with others employed in 1970 or 1975.

c Excludes general managers.

$d$ Excludes architects and other engineers and technicians in the following branches: building and construction, electronics and telecommunications, mechanical branches, chemical branches and metallurgy, and mining. 
Table 4. Occupations with an increased incidence of myocardial infarction among the women. $(95 \% \mathrm{Cl}=95 \% \mathrm{confidence}$ interval)

\begin{tabular}{|c|c|c|c|c|}
\hline \multirow[t]{2}{*}{ Occupation ${ }^{a}$} & \multicolumn{2}{|c|}{$\begin{array}{l}\text { Relative risk (RR) adjusted } \\
\text { for age, county and } \\
\text { calendar year }\end{array}$} & \multicolumn{2}{|c|}{$\begin{array}{l}\text { Relative risk (RR) adjusted } \\
\text { for age, county and } \\
\text { socioeconomic group }\end{array}$} \\
\hline & RR & $95 \% \mathrm{Cl}$ & RR & $95 \% \mathrm{Cl}$ \\
\hline Unskilled manual workers ${ }^{b}$ & 2.5 & $1.2-5.0$ & 2.3 & $1.2-4.7$ \\
\hline Bench carpenters and cabinet makers ${ }^{b}$ & 2.0 & $1.0-3.9$ & 2.0 & $1.0-3.9$ \\
\hline Certain civilian protective service workers ${ }^{b, c}$ & 2.0 & $1.0-3.8$ & 1.9 & $1.0-3.6$ \\
\hline $\begin{array}{l}\text { Electrical fitters and wiremen, radio and } \\
\text { television assemblers and repairmen, recording, } \\
\text { sound and light equipment operators }\end{array}$ & 1.8 & $1.0-3.3$ & 1.6 & $0.9-2.9$ \\
\hline $\begin{array}{l}\text { Toolmakers, machine-tool setters and operators, } \\
\text { machinery fitters and machine assemblers }\end{array}$ & 1.8 & $1.1-3.1$ & 1.5 & $0.8-2.6$ \\
\hline Kitchen assistants & 1.5 & $1.0-2.1$ & 1.4 & $0.9-2.0$ \\
\hline Building caretakers ${ }^{\mathrm{b}}$ & 1.5 & $1.1-2.1$ & 1.4 & $1.0-1.9$ \\
\hline Practical nurses and hospital orderlies & 1.4 & $1.1-1.8$ & 1.3 & $1.0-1.7$ \\
\hline Cleaners & 1.2 & $1.0-1.5$ & 1.1 & $0.9-1.4$ \\
\hline Shop assistants ${ }^{b}$ & 1.1 & $1.0-1.2$ & 0.9 & $0.8-1.0$ \\
\hline
\end{tabular}

a Persons working in a certain occupation in both 1970 and 1975 unless marked with superscript $b$.

b Persons working in the occupation in 1970 or 1975, compared with others employed in 1970 or 1975.

c Excludes firefighters, policemen, customs surveillance officials, and prison and reformatory officials.

Table 5. Occupations with a decreased incidence of myocardial infarction among the women. ( $95 \% \mathrm{Cl}=95 \%$ confidence interval)

\begin{tabular}{|c|c|c|c|c|}
\hline \multirow[t]{2}{*}{ Occupation ${ }^{a}$} & \multicolumn{2}{|c|}{$\begin{array}{l}\text { Relative risk (RR) adjusted } \\
\text { for age, county and } \\
\text { calendar year }\end{array}$} & \multicolumn{2}{|c|}{$\begin{array}{l}\text { Relative risk (RR) adjusted } \\
\text { for age, county and } \\
\text { socioeconomic group }\end{array}$} \\
\hline & RR & $95 \% \mathrm{Cl}$ & RR & $95 \% \mathrm{Cl}$ \\
\hline Teachers in theoretical subjects ${ }^{b}$ & 0.4 & $0.3-0.7$ & 0.5 & $0.3-0.8$ \\
\hline Government legislative and administrative work ${ }^{b}$ & 0.6 & $0.4-0.8$ & 0.7 & $0.5-1.0$ \\
\hline $\begin{array}{l}\text { Teachers in painting, music, and physical } \\
\text { education }{ }^{b}\end{array}$ & 0.6 & $0.4-0.9$ & 0.7 & $0.4-1.0$ \\
\hline Physiotherapists, occupational therapists ${ }^{b}$ & 0.6 & $0.3-1.0$ & 0.7 & $0.4-1.2$ \\
\hline Registered nurses ${ }^{b}$ & 0.7 & $0.6-1.0$ & 0.9 & $0.7-1.2$ \\
\hline Secretaries, typists and related work & 0.8 & $0.7-0.9$ & 1.0 & $0.9-1.1$ \\
\hline Waitresses $^{b}$ & 0.9 & $0.7-1.0$ & 0.8 & $0.6-0.9$ \\
\hline
\end{tabular}

a Persons working in a certain occupation in both 1970 and 1975 unless marked with superscript b.

b Persons working in the occupation in 1970 or 1975, compared with others employed in 1970 or 1975.

tive risk estimates were often somewhat closer to the null value, and for some occupations listed in the tables there was no increased or decreased incidence in these analyses.

\section{Smoking}

For both genders, the proportion of smokers and the proportion of smokers of more than 10 cigarettes a day differed about $5 \%$ or less when the subjects in occupations with an increased or decreased incidence were compared to all those employed (table 6). For the men, the proportion of smokers was somewhat greater in occupations with an increased incidence of myocardial infarction and somewhat smaller in occupations with a decreased incidence than in all occupations.

\section{Discussion}

In the present study, large differences were found among certain occupational groups regarding the incidence of a first myocardial infarction for both the men and the women. The relative risk was 3 to 10 times greater for the subjects in occupations with the highest incidence than for those in occupations with the lowest incidence. An increased incidence was observed particularly for the persons in some occupations in production work (men and women), transport and communications work (men), and service work (women). Low relative risks were found mainly for the subjects in occupations demanding a high education. Altogether, subjects in occupations with an increased or a decreased incidence were suggested to differ only 
Table 6. Percentage of current smokers and smokers of more than 10 cigarettes a day among all those employed and among persons in occupations with an increased or decreased incidence of myocardial infarction - data from the Swedish Twin Register.

\begin{tabular}{|c|c|c|c|c|c|c|c|c|c|c|c|c|}
\hline & \multicolumn{6}{|c|}{ Men } & \multicolumn{6}{|c|}{ Women } \\
\hline & \multicolumn{3}{|c|}{ Current smokers } & \multicolumn{3}{|c|}{$\begin{array}{l}\text { Current smokers of more } \\
\text { than } 10 \text { cigarettes a day }\end{array}$} & \multicolumn{3}{|c|}{ Current smokers } & \multicolumn{3}{|c|}{$\begin{array}{l}\text { Current smokers of more } \\
\text { than } 10 \text { cigarettes a day }\end{array}$} \\
\hline & \multirow[t]{2}{*}{$\%$} & \multicolumn{2}{|c|}{$\begin{array}{l}\text { Difference com- } \\
\text { pared with all } \\
\text { those employed }\end{array}$} & \multirow[t]{2}{*}{$\%$} & \multicolumn{2}{|c|}{$\begin{array}{l}\text { Difference com- } \\
\text { pared with all } \\
\text { those employed }\end{array}$} & \multirow[t]{2}{*}{$\%$} & \multicolumn{2}{|c|}{$\begin{array}{l}\text { Difference com- } \\
\text { pared with all } \\
\text { those employed }\end{array}$} & \multirow[t]{2}{*}{$\%$} & \multicolumn{2}{|c|}{$\begin{array}{l}\text { Difference com- } \\
\text { pared with all } \\
\text { those employed }\end{array}$} \\
\hline & & $\%$ & $95 \% \mathrm{Cl}$ & & $\%$ & $95 \% \mathrm{Cl}$ & & $\%$ & $95 \% \mathrm{Cl}$ & & $\%$ & $95 \% \mathrm{Cl}$ \\
\hline All those employed & 49.0 & . & . & 23.8 & . & . & 43.4 & . & . & 21.5 & . & - \\
\hline $\begin{array}{l}\text { Persons in occupa- } \\
\text { tions with in- } \\
\text { creased incidence }\end{array}$ & 54.6 & 5.6 & $-0.1-11.4$ & 27.2 & 3.4 & $-1.7-8.5$ & 45.2 & 1.8 & $-4.9-8.5$ & 20.9 & -0.6 & $-6.1-4.8$ \\
\hline $\begin{array}{l}\text { Persons in occu- } \\
\text { pations with de- } \\
\text { creased incidence }\end{array}$ & 43.7 & -5.3 & $-10.7-0.2$ & 20.6 & -3.2 & $-7.8-1.3$ & 43.5 & 0.1 & $-5.9-6.1$ & 22.6 & 1.1 & $-3.9-6.2$ \\
\hline
\end{tabular}

slightly from all those employed with regard to smoking habits.

The results of the present study are consistent with those of previous studies regarding increased rates of cardiovascular disease among motor-vehicle drivers (17-19) and decreased rates among subjects in occupations demanding a high education and among persons engaged in agricultural, horticultural, and forestry work (8). The results are also in agreement with the findings of an inverse relationship between socioeconomic group and coronary heart disease $(1,3)$.

The study base covered the period 1976-1984, and exposure conditions responsible for the observed increased or decreased incidence rates may have preceded this period by 10 years or more. Obviously, some of the differences observed in myocardial infarction incidence between the occupational groups in this study may not be present also in the 1990s. To follow changes of this kind, repeated studies are needed. Methods for such repeated studies are suggested by the design of the present investigation.

The method used in the present study to identify myocardial infarction cases has been found to be somewhat less efficient but still comparable to that of myocardial infarction community registers set up in a program of the World Health Organization (10). In Sweden, cases of acute myocardial infarction are almost invariably treated in hospitals, and hospital care is open to the whole population at a low cost. The medical information systems employed covered all hospitals in the five counties where acute medical cases were treated during the study period. To a large extent, cases of myocardial infarction that belonged to the study base but were treated outside these five counties were also identified through the central hospital discharge register. The national register of causes of death held all the deaths in the study base, and the autopsy rate of the fatal cases of acute myocardial infarction was $69 \%$. It seems reasonable to assume that a small number of diagnosed cases was lost from the study base and that the loss of cases was basically un- related to occupation, and thus that a nondifferential misclassification of disease was introduced.

Clinically unrecognized cases of myocardial infarction have been found to constitute a large proportion of all cases in a population (20), and these cases were not covered in the present study for obvious reasons. If there were differences between occupational groups in the proportion of these cases (eg, because of differences in the tendency to seek medical care for symptoms related to myocardial infarction), the relative risk estimates may have been biased. This source of error, however, is probably of less importance in analyses of mortality from myocardial infarction. We also performed analyses of myocardial infarction mortality in the different occupations, and the results from these analyses were basically similar to those concerning myocardial infarction incidence.

In the present study it was not feasible to review all cases with regard to fulfillment of defined diagnostic criteria for acute myocardial infarction. It has been indicated from previous studies that about $10-20 \%$ of patients discharged from hospitals in Sweden with a diagnosis of myocardial infarction may not fulfill the diagnostic criteria for acute myocardial infarction employed in a Swedish cooperative study $(21,22)$. However, many of the patients that did not fulfill these criteria were classified as possible infarctions or had been treated for a previous infarction.

A total of 386 of the cases in the present study were included in a previous examination of medical records with regard to fulfillment of diagnostic criteria for myocardial infarction. This procedure allowed comparisons of broad categories of occupational groups with regard to the proportion of myocardial infarction cases that did not fulfill these criteria. Very small differences $(<5 \%)$ were found regarding this proportion when subjects in transport, communications, and production work were compared with subjects in professional, technical, administrative, and managerial work. Likewise, only very small differences were observed when subjects in occupations with work in- 


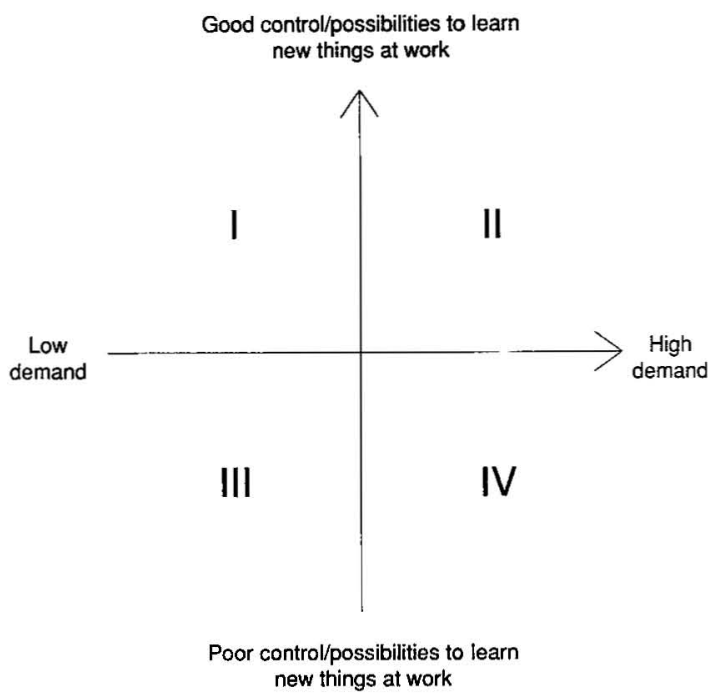

Figure 1. Schematic representation of the combination between demands on the one hand and degree of control and possibility to learn new things at work on the other.

volving much heavy lifting, according to a classification of work environment factors based on data from national surveys (23), were compared with subjects in occupations without heavy lifting.

In the relative risk estimates, age, calendar year, county, and socioeconomic group were taken into account by stratification. It may be reasonable to assume that the specificity was basically unrelated to occupation within the different strata and that therefore the presence of "false positives" tended to bias the relative risk estimates towards the null value.

In the present study, the goal was to consider only the first myocardial infarction episode for an individual. In the classification of first events, data about hospitalization for myocardial infarction during 1972-1975 were utilized, and the previous infarctions that were missed probably to a large extent occurred more than four years before the beginning of the study period. The reinfarction rate has been found to be particularly high early after a first infarction and then to decrease gradually (24). Thus, although a certain misclassification of first events in the present study is present, it seems very unlikely that it can explain the observed differences in myocardial infarction incidence.

A misclassification of occupation may have been due to incorrect or unspecific answers in the censuses, errors in the recording of the census data, or errors in the linkage of census data to cases and referents. However, at least for persons with the same occupation in both censuses, the misclassification of occupation was probably in general low. Information on occupation was collected from before the study period and in the same way for the cases and referents, and it is likely that the misclassification of occupation was unrelated to myocardial infarction occurrence. This result tends thus to bias the estimated relative risks towards the null value.

Since the misclassification of disease and occupation probably, in general, tended to bias the relative risk estimates towards the null value, these sources of error can hardly explain the observed large differences in the incidence of myocardial infarction between occupational groups. However, some actual increased or decreased incidence rates may have gone undetected because of this bias.

It has been indicated previously that a health-related selection of subjects from physically heavy occupations to physically light occupations may cause an artifactual excess risk of certain disorders, including circulatory disease, in the latter kind of occupations (25). Concerning "occupationally stable" persons, a selection of this kind could only have occurred more than five years before the infarction. For some occupations a health-related selection is a possible explanation for the observed increased or decreased incidence, but it seems unlikely that it can explain the large differences in incidence for occupational groups in the present study.

The observed differences in myocardial infarction incidence among occupational groups were probably due to both occupational and nonoccupational factors. It is likely that the established risk factors for myocardial infarction (smoking, blood pressure, and serum cholesterol) are of importance for the results. However, to explain the observed differences in myocardial infarction only by differences in these factors, large differences in the distributions of these factors would be required.

We found fairly small differences in smoking, on the average, between the subjects in occupations with an increased or decreased incidence of myocardial infarction as compared with all those employed. For certain occupations, however, the differences may have been larger, and it cannot be excluded that for some occupations differences in smoking habits was the reason for the observed increased or decreased incidence of myocardial infarction. Theoretically, it can be shown that, if the smoking prevalence among all employed persons is $50 \%$ and the observed relative risk is $\mathbf{1 . 5}$ and smokers have twice the risk of nonsmokers to develop myocardial infarction, stratification for smoking would yield a relative risk of 1.32 if the prevalence of smokers was $70 \%$ in the index occupation and 1.25 if the prevalence in the index occupation was $80 \%$.

Swedish and British studies have suggested that socioeconomic differences in coronary heart disease cannot be explained only by differences in smoking, blood pressure, and serum cholesterol $(1,3)$. It seems likely that also other risk factors for myocardial infarction were more prevalent among the subjects in occupations associated with an increased incidence of myocardial infarction than among the other subjects. 
Several work environment factors may have been of relevance for our results. A combination of high demand and poor control or few possibilities to learn new things at work (quadrant four of figure 1) has been associated with an increased risk of coronary heart disease $(23,26)$. In Sweden, a classification of occupations with respect to these and other work environment factors has previously been developed (23). According to this classification, a large proportion of the occupations, which in the present study were found to be associated with an increased incidence of myocardial infarction, involved this combined exposure (11 of 26 classified occupations; both genders). Only few of the occupations associated with a decreased incidence involved this combined exposure ( 4 of 32 classified occupations; both genders). According to this classification it was furthermore indicated that several of the occupations with an increased incidence and very few of the occupations with a decreased incidence involved exposure to heat, cold, heavy lifting, or noise.

These observations suggest that several factors in the work environment are of possible relevance to our findings. However, several other factors which are not occupational, but may be related to occupation, such as diet, alcohol consumption, social support, and early upbringing may also have been involved. Considering the magnitude of some of the differences, unknown interactions between risk factors may play an important role in explaining the findings.

\section{Acknowledgments}

The authors wish to thank Professor C Hogstedt, $\mathrm{Mr}$ $\mathrm{N}$ Plato, and Professor T Theorell for their comments on the manuscript and for their advice and support at different stages of the study. Mr $\mathrm{H}$ Kiviranta is thanked for his computer assistance.

The study was supported by grant number $88-0033$ from the Swedish Work Environment Fund.

\section{References}

1. Marmot MG, Rose G, Shipley M. Employment grade and coronary heart disease in British civil servants. J Epidemiol Community Health 1978;32:244-9.

2. Buring JE, Evans DA, Fiore M, Rosner B, Hennekens $\mathrm{CH}$. Occupation and risk of coronary heart disease. JAMA 1987;258:791-2.

3. Rosengren A. Coronary heart disease and mortality in relation to alcohol abuse and social factors [dissertation]. Göteborg; University of Göteborg, 1988.

4. Dobson AJ, Gibberd RW, Leeder SR, O'Connel DL. Occupational differences in ischemic heart disease mortality and risk factors in Australia. Am J Epidemiol 1985;122:283-90.

5. Marmot MG, McDowall ME. Mortality decline and widening social inequalities. Lancet 1986;2:274-6.

6. Marmot M, Theorell T. Social class and cardiovascular disease: the contribution of work. Int $\mathbf{J}$ Health Serv 1988;18:659-74.

7. Kristensen TS. Cardiovascular diseases and the work environment: a critical review of the epidemiologic litera- ture on chemical factors. Scand J Work Environ Health 1989;15:245- 64 .

8. Kristensen TS, Damsgaard MT. Hjerte/karsygdomme og arbejdsmiljö: oversigtskapitler og konklusioner; bind 1 [Cardiovascular disease and work environment: summary chapters and conclusions; volume 1]. Copenhagen; Arbejdsmiljöfondet, 1987. (Arbejdsmiljöfondets forskningsrapporter.)

9. Ahlbom A. Acute myocardial infarction in Stockholm - a medical information system as an epidemiological tool. Int J Epidemiol 1978;7:271-6.

10. Hammar N, Nerbrand C, Ahlmark G, Tibblin G, Tsipogionni A, Johanson S, et al. Identification of cases of myocardial infarction: hospital discharge data and mortality data compared to myocardial infarction registers. Int J Epidemiol 1991;20:114-20.

11. Cederlöf R, Friberg L, Lundman T. The interactions of smoking, environment and heredity and their implications for disease etiology. Acta Med Scand Suppl 1977;612:1-128.

12. Statistics Sweden. Meddelanden i samordningsfrảgor 1982:4 [Report on statistical co-ordination 1982:4]. Stockholm: Statistics Sweden, 1982.

13. Cederlöf $\mathbf{R}$. The twin method in epidemiologic studies on chronic disease [dissertation]. Stockholm: University of Stockholm, 1966.

14. Mantel N, Haenszel W. Statistical aspects of the analysis of data from retrospective studies of disease. J Natl Cancer Inst 1959;22:719-48.

15. Robins J, Greenland S, Breslow NE. A general estimator for the variance of the Mantel-Haenszel odds ratio. Am J Epidemiol 1986;124:719-23.

16. Sullivan K, Foster D. Depid. Epidemiol Monit 1987; $8: 10 / 2$.

17. Morris JN, Kagan A, Pattison DC, Gardner MJ, Raffle PAB. Incidence and prediction of ischaemic heartdisease in London busmen. Lancet 1966;2:553-9.

18. Netterström B, Laursen $P$. Incidence and prevalence of ischemic heart disease among urban bus drivers in Copenhagen. Scand J Soc Med 1981;9:75-9.

19. Rosengren A, Anderson K, Wilhelmsen L. Risk of coronary heart disease in middle-aged bus and tram drivers compared to men in other occupations: a prospective study. Int J Epidemiol 1991;20:82-7.

20. Kannel WB, Abbot RD. Incidence and prognosis of unrecognized myocardial infarction. N Engl J Med 1984; 311:1144-7.

21. Ahlbom A, Nordlander R. Application of diagnostic criteria in the diagnosis of myocardial infarction. Scand J Soc Med 1979;7:67-72.

22. Hammar N, Larsen FF, de Faire U. Are geographical differences and time trends in myocardial infarction incidence in Sweden real? - validity of hospital discharge diagnoses. Stockholm: Department of Epidemiology, Institute of Environmental Medicine, Karolinska Institute, 1991.

23. Alfredsson L, Spetz C-L, Theorell T. Type of occupation and near-future hospitalization for myocardial infarction and some other diagnoses. Int $\mathrm{J}$ Epidemiol 1985;14:378-88.

24. Ulvenstam G, Ảberg A, Bergstrand R, Johansson S, Pennert K, Vedin A, et al. Recurrent myocardial infarction: 1. natural history of fatal and non-fatal events. Eur Heart J 1985;6:294-302.

25. Östlin P. Occupational career and health: methodological considerations on the healthy worker effect [dissertation]. Uppsala (Sweden): University of Uppsala, 1989.

26. Karasek R, Baker D, Marxer F, Ahlbom A, Theorell T. Job decision latitude, job demands, and cardiovascular disease: a prospective study of Swedish men. Am J Public Health 1981;71:694-705.

Received for publication: 27 September 1991 